NRSIR 81-2294

\title{
Survey of United States Research Projects Publications in the Field of Fire Safety of Buildings and Structures
}

R. S. Levine, Editor

Co-Chairman, U.S.-U.S.S.R. Panel on Fire Resistance of Buildings and Structures Center for Fire Research National Engineering Laboratory U.S. Department of Commerce National Bureau of Standards

Washington, DC 20234

June 1981

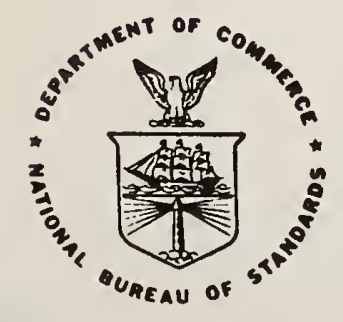





\section{SURVEY OF UNITED STATES RESEARCH \\ PROJECTS PUBLICATIONS IN THE FIELD \\ OF FIRE SAFETY OF BUILDINGS AND}

\section{STRUCTURES}

R. S. Levine, Editor

Co-Chairman, U.S.-U.S.S.R. Panel on Fire Resistance of Buildings and Structures

Center for Fire Research

National Engineering Laboratory

U.S. Department of Commerce

National Bureau of Standards

Washington, DC 20234

June 1981

U.S. DEPARTMENT OF COMMERCE, Malcolm Baldrige, Secretary NATIONAL BUREAU OF STANDARDS. Ernest Ambler, Director 



\section{FOREWORD}

This annotated literature search was prepared for transmittal to Dr. I. G. Romanenkov of the Soviet Ministry of Construction as part of a continuing US-USSR protocol (agreement) to cooperate in the field of "Fire Resistance of Buildings and Structures." Dr. Romanenkov is the USSR Co-Chairman of the panel. It is reproduced also as an NBS publication because of its possible value to English-speaking recipients. 
FOREWORD . . . . . . . . . . . . . . . . . . . iii

Abstract ..................... . . . v v

INTRODUCTION ...................... . . v v

1. TESTING MATERIALS FOR FLAMMABILITY, SMOKE GENERATION AND

TOXICITY IN FIRES, V. Babrauskas . . . . . . . . . . . . I 1

2. FIRE RESISTANCE OF STRUCTURAL COMPONENTS, D. Gross . . . . 5

3. METHODS FOR CALCULATING THE FIRE RESISTANCE OF CONSTRUCTION ELEMENTS, M. Abrams and T. D. Lin . . . . . . . . . 7

4. REVIEW OF COMPARTMENT FIRE MODELING AND RELATED SUBJECTS,

J. Quintiere and $W$. Jones . . . . . . . . . . 10

5. SPREAD OF FIRE TO NEIGHBORING STRUCTURES, B. Vogel . . . . 11

6. REVIEW OF U.S. ACTIVITY IN AUTOMATIC DETECTION AND SUPPRESSION OF FIRES, R. Friedman . . . . . . . . . . 11

7. FIRE PROTECTION COATINGS, M. Lieff ........... . 15

8. SAVING THE LIVES OF PEOPLE IN BUILDING FIRES, R. Paulsen . - 15

9. REFERENCES ......................... 17

APPENDIX: Fire Resistant Coverings . . . . . . . . . 31 
SURVEY OF UNITED STATES RESEARCH PROJECTS PUBLICATIONS IN THE

FIELD OF FIRE SAFETY OF BUILDINGS AND STRUCTURES - 1978-1980

R. S. Levine, Editor

\begin{abstract}
This report is an annotated bibliography of some 166 U.S. papers on fire safety research, published 19781980. Prepared as part of a US-USSR agreement to cooperate in this field, it includes chapters on testing materials for flammability, smoke generation and toxicity, fire resistance of structures, compartment fire modeling, automatic detection and suppression, and human response in fires.

Key words: Compartment fires; fire detection; fire endurance; fire modeling; fire tests; flammability; human behavior; smoke; suppression; toxicity.
\end{abstract}

\title{
INTRODUCTION
}

Each chapter of this annotated bibliography was prepared by a U.S. expert in that subject. Their names appear in the table of contents. 



\section{TESTING MATERIALS FOR FLAMMABILITY, SMOKE GENERATION,} AND TOXICITY IN FIRES

The concept of oxygen consumption measurements for use as a rate of heat release technique has been systematized at the National Bureau of Standards $(1.1)^{1}$. Common fuel materials have heats of combustion that vary between about 20 to $50 \mathrm{~kJ}$ per gram of fuel burned. As it turns out, the oxygen consumption is also in a proportional ratio, so that the heat released per gram of oxygen consumed is nearly constant. A value of $13.1 \mathrm{~kJ} / \mathrm{g} \mathrm{O}_{2}$ represents most common fuels to within \pm 5 percent. Further, for many fuels this ratio is about the same even when combustion goes to $\mathrm{CO}$ rather than $\mathrm{CO}_{2}(1.2)$.

The principles of oxygen consumption calorimetry have been applied to making measurements of entire room burning surfaces. The technique is useful for both instrumenting small, 1/4-scale tests, and for determining burning rate in full-scale room fires (1.3).

The design of isothermal rate of heat release calorimeters is difficult and costly thus many common designs are only moderately insulated and are not kept isothermal. Radiation-dependent losses in these may introduce serious error. One such instrument has been examined in detail (1.2) and it was demonstrated that significantly better results can be obtained if the oxygen consumption principle is used.

The flammability test most commonly used in the United States, the Steiner Tunnel, is typically used only for empirical comparisons of flame spread properties of materials. The flame spread measured is along the ceiling of a tunnel and is "with the wind." This type of flame spread geometry is always the most difficult to treat. Now, however, an analysis of the flow has been provided (1.4), based on detailed solutions of the two-dimensional conservation equations. Simple radiative terms were also included in this analysis.

A physical explanation for some anomalous flammability results seen in the steiner Tunnel is explained in (1.5) in terms of heat conduction theory.

Mass burning rates for several plastics, woods, and liquids have been measured $(1.6)$ in an apparatus first developed at Factory Mutual Research Corp. Heats of gasification and effects of oxygen fraction and external irradiance were also evaluated.

The construction of a simple but effective aspirated thermocouple for use in fire tests has been presented (1.7). An aspiration velocity of $\simeq 7 \mathrm{~m} / \mathrm{s}$ was recommended.

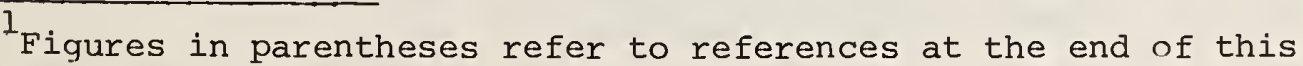
publication.
} 
Increased use of cellulose thermal insulation in the United States has brought concern about flammability characteristics of this material. To ensure a minimum level of safety, a two-part test has been developed (1.8). The first part is a variation of an existing test for the flammability of carpeting where the critical radiant flux required to sustain flame propagation is measured. For cellulose insulation this value has been set at $\geq 0.12 \mathrm{~W} / \mathrm{cm}^{2}$. The second part is a test for smolder propensity and involves cigarette ignition of a container filled with the insulation material at a controlled packing density. No more than 15 percent weight loss may occur if the insulation is to be accepted.

Radiative properties (absorption coefficient of the gases and flame temperature) were determined in (1.9) for several common plastics. The absorption coefficient for polymethylmethacrylate was $1.2-1.7 \mathrm{~m}^{1}$, for polypropylene was $1.7-2.2 \mathrm{~m}^{1}$, for polyurethane was $\simeq 1.3 \mathrm{~m}^{1}$, for polystyrene was $3.0-7.0 \mathrm{~m}^{1}$ and for polyoxymethylene was immeasurably small.

A review article has been published on recent results from tests of polymeric materials for ignitability, flash-fire propensity, flame spread rate, heat release rate, and smoke production (1.10).

For testing material properties related to burning rate a large number of standard tests are available in the U.S. Ideally, the choice is made on theoretical considerations. For some applications, however, it can be useful to have simply an empirical correlation or comparison of test results. Some 20 different materials were each tested in a radiant panel flame spread apparatus, a rate of heat release calorimeter, a bunsen burner test, a limiting oxygen index test and a thermogravimetric analyzer (1.11). Results showed little overlap among the test methods.

Fernandez-Pello and co-workers are continuing studies of flame spread, bcth by numerical solutions to the theoretical formulations, and by experimental studies on polymethylmethacrylate. Flame spread along the flow direction is considered in (1.12) for laminar, forced convection. Flame spread by natural convection against the flow direction is treated in (1.13).

The measurement of upward (with-the-wind) flame spread is typically quite difficult because of its swiftness. Preliminary exploration on developing a combined ignition and upward flame spread test for use with foam plastics has been reported (1.14).

A technique has been developed for the study of polymer flammability by coating the polymer on a thin metal wire and moving the wire at a steady speed across a heating zone (1.15). Heat transfer coefficients were determined that are applicable to this geometry. Polyvinylchloride samples were studied in detail with this technique (1.16). 
A proposal is made (1.17) to test fuel items for the possibility of causing room flashover by measuring mass or heat loss rates in open burning. Experimental data show that flashover can be expected when the fuel burning rate reaches 50 percent of stoichiometric, based on window ventilation air flows.

A simple theory was developed for the burning rate of thermoplastic and liquid pools in compartments (1.18). This theory shows that steady, flashed-over compartment fires are not possible for a fuel-lean condition.

A new version of the post-flashover compartment fire computer program COMPF has been issued (1.19). This program now incorporates recent advances in the description of pool fires.

The National Aeronautics and Space Administration has been coordinating a large effort in the understanding of aircraft fires, in the study of appropriate testing methods, and in the development of materials with improved fire performance. This work has implications for fires in buildings since the same testing principles can be exploited. The greatest emphasis has been on heat release rate, smoke development and toxicity. This work has been carried out primarily in the laboratories of the various aircraft manufacturers (1.20-1.23).

The testing of the flammability of interior linings for submarines and similar applications generally has required full-scale tests to achieve meaningful results. To reduce testing costs, a 1/4-scale test apparatus has been developed and validated against full-scale tests (1.24). This, again, is an approach of significant general validity, beyond submarines alone.

Extensive studies have been reported (1.25) on the use of a 1/3scale model compartment for predicting the fire temperatures in a fullsized room lined with polyurethane and similar foam materials.

Fires in mobile homes are a special problem in the United States because of their thin, combustible surfaces, crowded room arrangements, and limited exit capabilities. A five-year study was recently completed on the fire performance of mobile homes (1.26). The importance of providing proper protection near cooking ranges and of controlling flame spread behavior of the walls and ceilings was emphasized.

Increased efforts to promote solar heating installations have indicated the importance of avoiding the creation of new fire hazards by providing for a safe heat transfer liquid. The liquids currently used are combustible, but flash points can range from less than $100^{\circ} \mathrm{C}$ to more than $300^{\circ} \mathrm{C}$. A set of engineering guidelines has been proposed (1.27) to help determine suitable limits. 
Up until several years ago polychlorinated biphenyls were widely used as transformer dielectric fluids. They have now been banned because of toxicity problems. This has created difficulties since most replacement fluids are much more flammable. The primary hazards occur when the transformers are used inside buildings. A number of tests were conducted on these fluids and several engineering options were outlined, based on acceptable economic impact (1.28).

About ten years ago, rigid insulating plastic foams (primarily polyurethane and polystyrene) became so cheap and readily available that they were becoming widely used without proper engineering precautions, often mounted exposed in buildings. Serious fires and government concern eventually led to the formation of the Products Research Committee, which funded engineering studies designed to promote safer use of these materials. A total of 26 studies were completed, many of them in the areas of heat release and toxicology. A final report (1.29) has now been issued documenting the major findings of these studies.

A simplified single-step kinetics expression for char production was developed in (1.30) to predict the smoldering ignition potential of wood materials under long-time, low-temperature heating conditions. Ignition potential is taken to occur when 40 percent of the initial weight is lost.

The comparative ignition behavior of red oak and polymethylmethacrylate were studied using a laser heating source (1.31). It was shown that for auto-ignition the energy absorption by the gasphase decomposition products was critical for polymethylmethacrylate, but that for red oak the high surface temperature of the char also helps ignition. A constant surface temperature condition for ignition is seen for polymethylmethacrylate, but for red oak lower incident heat fluxes require higher surface temperatures.

Ignition tests on fabric/cushion combinations were reported in (1.32) for a wide range of materials at irradiances, $58-105 \mathrm{~kW} / \mathrm{m}^{2}$.

An improved sample holder and thermocouple assembly has been developed to enable better measurements of the ignition temperatures of tobacco and similar shredded combustibles to be made in the setchkin ignition apparatus (1.33).

Electric cables, while normally not representing high fuel loads can act as significant flame propagators. Even low flammability materials can cause serious flame spread and toxicity problems since the primary heating source is often a sustained over-current. An examination of current concerns in this area, along with results of tests on cable materials is given in (1.34).

The analysis of ignition and fire spread in an electrical cable tray is a complex problem. Some initial theoretical calculations have been developed to begin this analysis (1.35). 
Empirical studies of the effects of fire retardants are reported in great numbers in the chemical and patent literature. Worthly especial mention are the International symposium on Flammability and Fire Retardants (1.36) and the Fire Retardant Chemicals Association annual meeting (1.37).

Borax and boric acid have conventionally been used as fire retardant treatments for cellulosic products. Details of their behavior have not, however, been thoroughly known. New studies of cellulose insulation materials (1.38) have shown that while boric acid reduces the smoldering tendency and borax reduces flaming behavior, the introduction of borax is antagonistic to the successful use of boric acid for smolder reduction and that a greater amount of boric acid must then be used. Detailed relationships are given for computing this increase.

An example of the differing effectiveness of a fire retardant at low and at high heat flux conditions was given in (1.12).

We had expected during the 1979-1980 period to have developed a test method that would screen materials for unusual toxicity in fire. An interlaboratory evaluation of the test method has given consistent results. However, unexpected difficulties in comparing the toxicities of the products from full scale fire tests and the products from the test decomposer have delayed the adoption of the test method. Reference (1.40) is a good summary of our present status.

\section{FIRE RESISTANCE OF STRUCTURAL COMPONENTS}

The standard test method for determining the fire resistance of structural components--walls, partitions, columns, floors, roofs, beams and girders--is ANSI/ASTM E 119 "Standard Methods of Fire Tests of Building Construction and Materials." This test method is used in all U.S. building codes, and code officials make use of fire resistance test listings of which the most comprehensive are those of the American Insurance Association (2.1) and the Underwriters Laboratories Inc., (2.2). Since a large fraction of recent efforts have been directed toward analytical and calculational methods of estimating fire resistance (see Section 3), research testing has been limited to specific topics.

Several reports have been published on the fire resistance of concrete components. An extensive research project was completed to evaluate the thermal restraint during fire exposure of reinforced concrete floor and roof assemblies (2.3). Included in this program were (a) small slabs, ranging from $3 \mathrm{ft}$. by $3 \mathrm{ft}$. to $9 \mathrm{ft}$. by $9 \mathrm{ft}$., and of several shapes (flat; flat with edge beams; and ribbed); and (b) large $14 \mathrm{ft}$. by $18 \mathrm{ft}$. slabs, which simulated the interior and exterior spaces in a multi-bay building; these were of flat, waffle, and pan joist shape. During some of these tests, slab expansions in both directions were controlled to follow calculated expansion-versus-time 
relationships and the expansions and restraining forces were measured. In other tests, compressible pads were used to simulate realistic restraints in a fixed frame furnace. It was concluded that fixed frame furnaces may be used to simulate thermal restraints during standard fire resistance tests of concrete slabs.

The thermal and structural response of prestressed concrete slab strips and I-shaped beams were studied analytically and compared with experimental data (2.4). The predicted responses included temperature distributions, stress levels in concrete and steel, extent of concrete cracking, and deflections of the members exposed to the Standard ASTM E 119 fire exposure. In the analytical model, account was taken of non-linear thermal and structural behavior; including non-linear stressstrain behavior of steel and concrete, elevated temperature creep, temperature-dependent thermal properties, and combined convective and radiative heat transfer in the furnace. The experimental data and analytical results showed good agreement.

The structural damage caused by accidental fires in several types of concrete buildings and outdoor structures was described and evaluated by Gustaferro (2.5). Although the damage was generally similar to that experienced in standard fire resistance tests, a few unique anomalies were noted. Techniques for evaluating structural damage include visual inspections, non-destructive testing, laboratory tests of samples of concrete and steel, and on-site load tests. Restoration procedures are usually possible although removal and replacement of damaged portions may be dictated by economics.

A state-of-the-art summary of the fire safety aspects of polymeric materials used in buildings is available in book form (2.6). This volume includes a summary of building fire statistics, illustration of fire scenario techniques, a description of the fire characteristics of polymeric materials and a critical review of fire test methods. The interrelationship between building design factors and choice of materials is discussed.

A test program was conducted to establish fire performance criteria for structural sandwich assemblies used in housing (2.7). Fire performance was compared in a room corner-wall test and in the $8 \mathrm{ft}$. and $25 \mathrm{ft}$. tunnel furnaces. Sandwich panels consisting of Douglas-fir plywood and cores of either paper honeycomb, urethane or isocyanurate rigid foam boards were evaluated. Flame spread performance and smoke development of the core materials in the corner-wall test did not always agree with results on these materials in the tunnel furnaces. The corner-wall fire test was deemed to be a useful supplement to other laboratory fire tests for appraising the fire growth potential of materials and assemblies.

In another experimental program (2.8), compartment corner fire tests were conducted on polyurethane spray foam faced with three types of paneling: (1) prefinished plywood paneling, (2) gypsum wallboard and (3) plywood paneling over gypsum wallboard. These tests showed that fire 
involvement of the polyurethane foam was substantially delayed when protected by gypsum wallboard and that fire stops also had a beneficial effect.

The fire performance of structural flakeboard made from forest residues was examined by laboratory tests for fire endurance, fire penetration, room corner-wall performance, $8 \mathrm{ft}$. and $25 \mathrm{ft}$. tunnel furnace exposures, rate of heat release and smoke development (2.9).

The penetration of fire-rated walls and floors by mechanical and electrical service devices, which has been a problem area for many years, has been more actively studied in recent years. One report reviewed the accumulation of test data on fire spread in structures containing plastic pipe for plumbing and drain-waste-vent systems (2.10). Another study described fire endurance tests for evaluating firestopping for cable penetrations in masonry walls and floors (2.11). The sealing materials investigated were silicone room-temperature vulcanizing (RTV) foam, bulk ceramic fiber, fiber board, cellular concrete, and coated Marinite panels. In another series of large-scale fire tests, cable penetration fire stops were evaluated using liquid fuel pan fires and small and large-scale furnaces (2.12). The ASTM E 119 furnace exposure was found to be the most reproducible test. Both small and large furnaces were characterized in terms of temperature and radiant and total energy fluxes. The effect of the following parameters was examined: furnace pressure; hole area filled with cabling; and structure and mounting details. A procedure for evaluating cable penetration fire stops in rated fire barriers has been standardized by the Institute of Electrical and Electronics Engineers (2.13).

Analytical predictions of thermal and structural response to fire were compared with experimental fire test data on protected steel beam and floor systems composed of spray-insulation covered W $12 \times 27$ beams supporting steel decking with 4 in. of lightweight concrete topping (2.14). Both composite and noncomposite assemblies, simply supported with sliding and hinged supports, were tested and analyzed on the basis of midspan deflections and the development of plastic zones and hinges. Overall agreement in fire resistance times was good.

\section{METHODS FOR CALCULATING THE FIRE RESISTANCE OF CONSTRUCTION ELEMENTS}

In the United States the fire resistance of construction elements is mostly determined by fire tests following a standard method recommended by the American Society for Testing and Materials. However, the computational methods have been accepted as supplemental tools in determining the fire endurance of structural elements. 
The fire resistance calculation requires temperature dependent data on the thermal and mechanical properties of the material involved. These data are generally obtained through tedious experimental work in laboratories. Since 1950 many papers have been published in the United States and other countries in this research area. Abrams reported a summary of information on inorganic materials (3.1, 3.2). After the material properties at high temperature became available, calculation methods for the fire resistance of structural elements have been developed. It is interesting to note that papers on the calculation of fire resistance started to appear in technical journals in the early part of the $1960 \mathrm{~s}$.

For the past two decades, fire research laboratories across the country have conducted many projects to study the fire resistance of structural elements, among them a great number of projects including theoretical analysis (3.3). Engineers in the United States have been in favor of using numerical solutions for the heat transfer and thermal stress problems. In general finite difference and finite element techniques have been applied in solving the thermal and stress problems, and the analytical solution has been utilized to prepare criteria for design.

The following discusses the major computational work in North America in the period from 1978 to the present.

\section{Thermal Analysis}

Lie extended his earlier study on the calculation of heat transfer to include various factors that influence the temperatures in concrete exposed to fire (3.4). This report presents a set of representative thermal property data for siliceous concrete at temperatures of $50^{\circ} \mathrm{F}$ to $1275^{\circ} \mathrm{F}$. The set can be used as standard thermal properties for calculating the fire resistance of concrete slabs.

Ellingwood and Shaver used the finite element and forward difference time integration technique to solve the heat flow problem in concrete beams (3.5). Convective and radiative heat transfer mechanisms were considered for the boundary condition on the exposed surface of the heated elements. A computer program was subsequently developed at the National Bureau of Standards, that can handle problems of different fire exposures, such as the ASTM E-119 standard fire, and a High Intensity short Duration fire.

An isothermal program involving fire tests of 32 full scale reinforced concrete beams was completed in the Fire Research Laboratory of the Portland Cement Association. Lin developed a mathematical model using the finite difference method for the transient heat flow in heated concrete elements (3.6). The program was then refined with the test result obtained from the test program. This program takes account of the temperature variation on the exposed surface, that is known as a viewfactor. The program computes one as well as two dimensional heat flow in concrete slabs, and beams of rectangular and tee cross sections, made with siliceous, carbonate and lightweight aggregate concretes. 
Nizamuddin and Bresler presented a mathematical model for the structural response of reinforced concrete slabs in fire (3.7). A finite element method was used in conjunction with an iterative approach within time steps to assess displacements at the nodal points. At each nodal point the equilibrium between the external load and internal stresses is constantly maintained. The program solves problems of any boundary conditions and reinforcing placement.

The National Bureau of Standards and the Portland Cement Association jointly funded an extensive research program, studying the effect of restraint on the fire endurance of slabs, of which an isolated area is exposed to fire. The program consisted of fire tests of 13 small slabs and $104.25 \mathrm{~m}$ by $5.5 \mathrm{~m}$, various type slabs and the development of a computer program to simulate the structural behavior of floor and roof assemblies during fire (3.8). The computer program comprises thermal analysis and stress analysis. In the stress analysis, the plane stress theory was used to formulate a system of metric equations that incorporate the nonlinear, thermal and mechanical properties of concrete and steel. A scaling factor was developed to separate the exposed area from the unexposed area of a floor system so that the elasto-plastic and elasticinelastic theories can be properly applied in the solution. The program is capable of predicting the expansion, stress distributions, restraining forces and crack patterns for flat slabs, pan-joist slabs and waffle slabs during fires.

Bresler presented a mathematical model using finite element technique for the fire response of prestressed concrete members (3.9). The program considers the non-linear stress-strain relationship and creep of concrete and steel at high temperature. The outputs of the program are basically stresses, cracks, and deflections.

\section{Analytical Procedure}

Gustaferro discussed the use of analytical procedures for determining the fire resistance of concrete members (3.10). The discussion suggested that the strength design procedure is adequate for the computation of the fire resistance of reinforced concrete structures exposed to fires. In this connection the PCI Fire Committee prepared a manual that has been approved by one model code organization as an alternate method for determining fire resistance. Detailed information on the computational procedure was presented in a special publication of the American Concrete Institute (3.11). Gustaferro's recommendation has been supported by the PCA test results of continuous reinforced concrete beams (3.12).

Lie developed design formulas for calculating the fire resistance of structural members (3.13). To simplify the computation graphic methods were also included. 
Byrne reported a comprehensive theoretical study on the behavior of load bearing masonry walls subjected to fire (3.14).

Schaffer presented methods for calculating the fire resistance of wood structural members (3.15). The paper reveals methods for reducing the cross section due to charring and of the buckling effect on compression members due to reduction of stiffness.

A review of the calculation approach to the design of structural steel members exposed to fire has been prepared by Jeanes (3.16). This work includes a discussion of the changes in material properties, and characteristics of the fire environment. A review of the approach taken by several of the calculation methods now published is also included.

\section{REVIEW OF COMPARTMENT FIRE MODELING AND RELATED SUBJECTS}

Over the last several years an effort has been made to develop mathematical approaches for the prediction of fire development in a compartment. Two approaches have been employed. The first is termed "field modeling" and solves the basic conservation equations in time and for a two dimensional space $(4.1,4.2)$. The equations solved are generally written in differential form. The goal is to include as many combustion and related phenomena as can practically be dealt with on present computers. The intent is to examine the details of physical phenomena. The second approach has been termed "zone modeling". It divides the compartment space into distinct zones; each zone characterized by its homogeneity or its phenomenological integrity. For example, the zones include the fire plume, the upper and lower gas regions, and the solid boundary. Researchers in this area have developed computer codes utilizing the zone concept to address fire spread and the burning characteristics of a wide variety of materials in a compartment (4.34.9). Related studies include a model for a fully-developed room fire (4.10), fire in a closed room (4.11), possible instabilities in room development (4.12), and a two-room model (4.13).

The zone model approach relies on a quantitive model for each component process in the system. Its concept also enables the system to be decomposed into phenomena that can be studied individually. Motivated by this need, as well as the desire to understand fire phenomena more fully, many studies have been made leading to a quantitative prediction for some facets of fire growth. Some selected studies will be cited here to indicate the scope and nature of this work.

Studies on fire plumes have investigated entrainment (4.14), smoke transport (4.15), unsteady effects (4.16), and radiative heat transfer (4.17). Radiation has also been studied for smoke layers in enclosures (4.18, 4.19), and a review is available (4.20). Fundamental studies on flame spread have addressed chemical kinetics (4.21), the effects of gravity and pressure (4.22), and the effects of oxygen concentration and 
the speed of the ambient flow directly opposed to the flame spreading direction (4.23). Studies on forced flow flame spread have also been performed (4.24-4.26). Analysis on burning rate have included theoretical (4.27) and experimental (4.28) for walls, and the effects of oxygen concentration and external radiation (4.29). Scaling investigations have been addressed through atmospheric Fronde number scaling (4.30), pressure modeling (4.31), and mathematical techniques (4.32). Probabilistic flame spread analyses have also been done (4.33).

Several review articles have appeared on developments in fire phenomena and modeling $(4.34-4.36)$ and on spread from a compartment (4.37).

\section{SPREAD OF FIRE TO NEIGHBORING STRUCTURES}

The only reference located in a literature search is a paper by Ashok T. Modak and L. Orloff (5.1). This paper presents a method for calculating radiative heat transfer to an adjacent tank from fire involving insulation on tank exteriors. An approximate method for calculating the radiative flux from an ignition source is also provided. Results are generalized to allow convenient estimates of safe separations for a range of tank sizes, fire intensities and critical ignition fluxes. wind effects are not considered in this study.

\section{REVIEW OF U.S. ACTIVITY IN AUTOMATIC DETECTION AND SUPPRESSION OF FIRES}

\section{Detection}

The past decade has seen a tremendous increase in the number of smoke detectors installed in residences in the United States. About half of the U.S. homes now have smoke detectors. Both photo-electric and ionization-type units have been used, sometimes battery operated and sometimes hard-wired. While there is no national law reauiring smoke detectors, many cities, counties, and states now have laws at least requiring detectors in new residential construction, and sometimes in existing construction. Furthermore, battery-operated detectors are widely advertised and may be purchased for as little as $\$ 10$ or $\$ 15$ and are easily installed by the homeowner.

Harpe and Christian (6.1) have described the development of a new procedure for testing residential smoke detectors which simulates smoldering combustion of upholstery materials. 
Nelson (6.2) has developed a probability analysis of the mathematical relation between the "unprotected time" (assuming a detector has failed in the interval between tests) and the years of service of the detector, with the interval between tests being a parameter. Accordingly, the advantage of periodic testing may be seen.

Litton (6.3) has discussed a procedure for optimizing the design of ionization-type smoke detectors, and points to a way by which increased reliability can be obtained without reducing sensitivity.

Solomon and Reiss (6.4) describe the requirements for a satisfactory combined ionization/photoelectric smoke detector, so that a fire producing either small or large particles could be detected sensitively.

The importance of a reference photometer and reference ionization detector in improving the reliability of smoke detectors is discussed by Bukowski and Mulholland (6.5). Recent developments in smoke detector technology are highlighted and theoretical as well as practical experience in regard to detector performance is summarized. Comparison of the theoretically predicted response of smoke detectors as a function of particle size with measured values is given. A monodisperse aerosol generator, an electrical aerosol analyzer with a size sensitivity from 0.01 to $1 \mu \mathrm{m}$, and an optical particle counter are described. The size distribution, mass and number concentration, optical density, and coagulation frequency for smoke from burning heptane and smoldering cotton lamp wick are presented. It is shown that a Junge type size distribution provides a good fit to the measured size distribution for both fresh and aged smoke.

Street et al. (6.6) have built a prototype fire detection system intended for a ship or submarine, where high sensitivity must be achieved by digital logic, programming to suit the detector's location, dual

detectors, and environmental averaging (accomplished by syphoning a small portion of the total air flow into an averaging flask, thereby smoothing out environmental fluctuations).

Johnson (6.7) has reviewed the possibility of hazard associated with the radioactive isotopes used in ionization-type smoke detectors.

More $(6.8)$ has studied the false-alarm rate of smoke detectors in a group of homes in Texas which were connected to a central station. They found roughly 0.05 false alarms per month per house. Of 1,496 alarms received in a given period, only 27 corresponded to fires. Over half of the false alarms were due to activation by cooking or fireplace activity. About one-fourth were due to mechanical problems with the system. About three-fourths of the unnecessary alarms were resolved by telephone; i.e., no equipment was dispatched. 
Bukowski (6.9) has studied the performance of smoke detectors in mobile homes.

Several scientific studies have been reported on the formation and movement of smoke. Powell et al. (6.10) have measured particle sizes of smokes produced from burning wood and PVC in environments at various temperatures from $20^{\circ} \mathrm{C}$ to $300^{\circ} \mathrm{C}$. Different effects of environmental temperature on particle size are found for smoldering vs. flaming combustion.

Heskestad and Delichatsios (6.11) have established generalized relationships for the velocity of radial motion and dilution rate of smoke for a fire burning under a flat inert ceiling. It is necessary to know the time-dependent rate of fire growth and the proportion of smoke in the combustion products in order to predict detector response at a particular location under the ceiling.

Zukoski and Kubota (6.12) have described a computer model for smoke movement caused by a fire in one room of a two-room structure. The gas in each room is assumed to be divided into two homogeneous layers. Buoyancy is the driving force. Entrainment occurs in the doorway between the rooms as well as in the original fire plume.

Fires may be detected not only on the basis of smoke but alternately by detecting gases such as $\mathrm{CO}, \mathrm{CO}_{2}, \mathrm{NO}_{\mathrm{x}}$, and organic acids. Rajan et al. (6.13) have made an exploratory study of adsorption of such gases on metal surfaces, coated in some cases with organic metal chelates. photoelectric effects were observed at the surface, the data suggesting that a fire detection system could be developed.

Willey (6.14) has analyzed factors leading to unsuccessful smoke detector performance in residential occupancies. He reviewed 23 such incidents; 10 cases involved improper installation or maintenance, and 12 cases involved inadequate response of people, either failure to be aroused ( 5 cases) or evacuation problems ( 7 cases).

\section{Suppression}

Heskestad (6.15) has written a review of the scientific knowledge of how water acts to suppress a fire. His review has 29 references. He shows that five different studies of extinction of wood fires yield a critical application rate between 1.5 and 3 grams of water per square meter of surface per second. Considerably smaller rates than this will prevent spread (as opposed to extinction). Experiments with various plastics showed critical water application rates for extinction ranging from $1.2 \mathrm{~g} / \mathrm{m}^{2} \cdot \mathrm{s}$ for polymethyl methacrylate (horizontal) to $4.4 \mathrm{~g} / \mathrm{m}^{2} \cdot \mathrm{s}$ for polyethylene (horizontal). When an external radiation flux was supplied, these values increased substantially. Extinguishment of liquid pool fires is also discussed in the review. 
Corlett and Williams (6.16) propose a framework for mathematical modeling of the suppression of open fires, with emphasis on water application. The approach involves a "length scale of coherent flaming," with suppression occurring when this length is reduced below a given value. The gasification rate of the fuel is considered to depend on energy feedback from the flame and on suppressive action, with a possible time lag. The effect of charring is considered. Transient flaming may occur when diffusional control gives way to a regime of premixed flames. Definitive large-scale testing is needed to evaluate the critical parameters of the model and corroborate it.

Sibulkin et al (6.17) have compared effects of nitrogen with $\mathrm{CF}_{3} \mathrm{Br}$ on the burning of vertical plastic rods. Both "fully burning" (ignited at the bottom) and downward burning configurations are studied, and the sensitivity to agents is found to depend on burning configuration. The "fully burning" configuration is less sensitive to oxygen concentration than the downward burning configuration and continues burning down to lower concentrations. Thus, the "limiting oxygen index" test, based on downward burning, can be misleading. The mechanisms leading to extinction are discussed.

Ball and pietrzak (6.18) have used a computer simulation of compartment fires in which water spray from a fire hose is being applied. The simulation follows the fire history from flashover through the period of water application to either knockdown of the fire or burnout. The results are said to provide a basis for future hardware development and experimental testing, seeking more effective fire control with smaller water usage.

On the more practical level, Yao (6.19) has prepared a 4l-page review of the performance of automatic sprinkler systems. He considers the optimization of sprinkler systems and reviews the long-range research program at Factory Mutual Research to provide a rational basis for this optimization. He discusses: laboratory flammability tests; intermediate-scale combustibility tests of various commodities (of the order to $10 \mathrm{~m}^{3}$ ); time-dependent heat release rates and plume velocities derived from such tests; extinguishability tests on this scale, either with ceiling sprinklers or by dripping water directly on the commodity; sprinkler discharge through fire plume; cooling of ceiling jet by spray; response characteristics of the sprinkler (i.e., the time lag before it opens); and discussion of how to combine knowledge of these factors with full-scale tests in order to optimize sprinklers for: (a) residential fires (life safety); (b) warehouse fires involving plastic storage. He describes how a "large-drop" sprinkler (16-mm orifice) has advantages over a more conventional (14-mm orifice) sprinkler in combatting "high-challenge" fires which possess strong fire plumes. The large drops have greater capability of penetrating the fire plume; however, they have reduced cooling capacity, which calls for constraints on the minimum system operating pressure. 
Moore (6.20) has reviewed a series of field tests in a two-story, single-family dwelling to evaluate a prototype quick-response residential sprinkler. This device responds to a given heat exposure from five to ten times as fast as commercially available sprinklers. The result is better fire control with fewer sprinklers and lower installation cost. About 60 fire tests were conducted, and the results validated the concept.

Suchomel and Castino (6.21) have carried out a series of fire tests in simulated living rooms, utilizing "extended coverage" sidewall sprinklers, and determining their response times as affected by location, ceiling height, and air movement, and utilizing ceiling-mounted "control" sprinklers. The results indicated that extended coverage sidewall sprinklers, installed either singly or multiply as appropriate, can represent a viable response to the need for fire protection, when area and ceiling height limitations are recognized.

Ault (6.22) has discussed lower-cost piping systems using thin-wall pipe for automatic sprinkler systems.

\section{FIRE PROTECTION COATINGS}

The formulations used for coatings in the United States are commercial secrets of the firms that make them. Hence, there are few if any publications that give information on composition. However, the fire resistant properties of these coatings are published. Prof. Morris Lieff has updated his paper on this subject for our panel. The revised paper is enclosed as an appendix to this report (7.1).

\section{SAVING THE LIVES OF PEOPLE IN BUILDING FIRES}

The references listed in this section cover a wide range of research done in the general area of human behavior and fire emergencies. Much of this work has been sponsored by the U.S. Department of Health, Education, and Welfare (now called the Department of Health and Human Services) in cooperation with the National Bureau of Standards (NBS). Also included are a few papers by U.S. researchers not associated with NBS, as well as some foreign papers published in an NBS conference proceedings.

The research covers the range of possible reactions of those involved in a fire, from initial awareness of the emergency through a variety of coping reactions, including evacuation responses. Information and research findings relative to efforts to prevent or prepare for fire emergencies are also provided through consideration of such topics as arson, education and training, or management planning. 
References (8.1) through (8.7) at the end of this chapter deal with the problems of alerting occupants to the existence of a fire emergency and communicating to them the nature of the emergency and appropriate courses of action. References (8.8) through (8.17) present analyses of the evacuation process, including some computer models. In references (8.18) and (8.19), the psychological determinants of arson are explored. Some descriptive and analytical reports on fire incidents are provided in references (8.20) through (8.31).

Two major conferences in the area of human behavior and fires have been held at NBS. Proceedings from both of these conferences have been published, and they are listed as references (8.32) and (8.33).

The Second International Seminar on Human Behavior in Fire Emergencies met in October 1978, with representatives from the United States, Great Britain, France, Japan, Canada, and west Germany. Papers were presented on a variety of topics including fire safety analysis, evacuation behavior, panic, and case studies of fire incidents.

The Conference on Fire and Life Safety for the Handicapped was held in November 1980. Recent governmental regulations have worked to make buildings used by the public increasingly accessible to the handicapped. This has led to concern over whether there is adequate provision for the life safety of the handicapped under fire conditions in these same buildings. To address these life safety problems, at this NBS Conference, six panels met simultaneously on the topics of alarm systems, egress, refuge, self-protection, management actions, and emergency service actions--as they relate to the special problems of the handicapped.

One area of current research for the Center for Fire Research is the development of a system to evaluate the fire safety of communitybased group homes for developmentally disabled adults and children (mentally retarded, cerebral palsied, etc.). The recent trend in the U.S. is to place moderately disabled persons, who do not live with their families, in small groups in a homelike setting rather than in large institutional settings. These small group homes require more engineered fire safety than a typical family home, but less than, for example, an institution like a nursing home for the aged. It is assumed that many of the group home residents can assist in their own evacuation in the event of fire. The new system being developed is designed to determine the level of fire safety needed for a group home relative to the difficulty of evacuating the residents. There is not yet a published reference on the system itself. However, some background reports have been produced, and these are listed here as references (8.34) through (8.36). 


\section{REFERENCES}

Chapter 1

(1.1) Huggett, C., Estimation of Rate of Heat Release by Means of Oxygen Consumption Measurements, Fire and Materials, Vol.4, 61-65 (1980).

(1.2) Krause, Jr., R. F. and Gann, R. G., Rate of Heat Release Measurements Using Oxygen Consumption, Journal of Fire and Flammability, Vol. 11, 117-130 (1980).

(1.3) Sensenig, D. L., An Oxygen Consumption Technique for Determining the Contribution of Interior Wall Finishes to Room Fires, U.S. National Bureau of Standards Technical Note 1128, Washington, DC 20234 (1980).

(1.4) Carrier, G. F., Fendell, F. E., and Feldman, P. S., Wind-aided Flame Spread Along a Horizontal Fuel Slab, Combustion Science and Technology, Vol. 23, 41-78 (1980).

(1.5) McGuire, J. H. and D'Souza, M. V., Flammability Merit sequence and Specimen Homogeneity, Fire Technology, Vol. 14, 273-278 (Nov. 1978).

(1.6) Petrella, R. V., The Mass Burning Rates of Polymers, Wood and Organic Liquids, Journal of Fire and Flammability, Vol. 11, 3-21 (1980).

(1.7) Newman, J. S. and Croce, P. A., A Simple Aspirated Thermocouple for Use in Fires, Journal of Fire and Flammability, Vol. 10, 326-336 (1979).

(1.8) Lawson, J. R., Interlaboratory Evaluation of the Attic Floor Radiant Panel Test and Smoldering Combustion Test for Cellulose Thermal Insulation, NBSIR 79-1588, U.S. National Bureau of Standards, Washington, DC 20234 (1979).

(1.9) Markstein, G. H., Radiative Properties of Plastics Fires, pp. 1053-1062 in 17th (International) Symposium on Combustion, Leeds, England (1978).

(1.10) Hilado, C. S. and Murphy, R. M., Fire Response of Organic Polymeric Materials (Organic Materials in Fire: Combustibility), pp. 76-105 in Design of Buildings for Fire Safety (STP 685). American Society for Testing and Materials, Philadelphia, PA (1979).

(1.11) Nicholas, E. B., Evaluation of Existing Flammability Test Methods by Comparison of the Flammability Characteristics of Interior Materials (FAA-NA-79-46), U.S. Federal Aviation Administration (1979).

(1.12) Fernandez-pello, A. C., Flame Spread in Forward Forced Flow, Combustion and Flame, Vol. 36, 63-78 (Sept. 1979).

(1.13) Fernandez-Pello, A. C. and Santoro, R. J., on the Dominant Mode of Heat Transfer in Downward Flame Spread, pp. 1201-1209 in 17th (International) Symposium on Combustion, Leeds, England (1978). 
(1.14) Annamalai, A. and Sibulkin, M., Ignition and Flame spread Tests of Cellular Plastics, Journal of Fire and Flammability, Vol. 9, 445-458 (1978).

(1.15) Hunter, L. W. and Grunfelder, C., Heat-Transfer Measurements in the Moving-Wire Technique for Studying Polymer Flammability, Combustion and Flame, Vol. 34, 265-274 (April 1979).

(1.16) Hunter, L. W., et al., Combustion of Polyvinylchloride Studied by a Low-Pressure Moving-Wire Technique, Combustion and Flame, Vol. 35, 169-177 (June 1979).

(1.17) Babrauskas, V., Estimating Room Flashover Potential, Fire Technology, Vol. 16, 94-103, 112 (May 1980).

(1.18) Babrauskas, V. and Wickstrom, U. G., Thermoplastic Pool Compartment Fires, Combustion and Flame, Vol. 34, 195-202 (March 1979).

(1.19) Babrauskas, V., COMPF2 -- A Program for Calculating Post-Flashover Fire Temperatures, National Bureau of Standards Technical Note 991 (1979), Washington, DC 20234.

(1.20) Kourtides, D. A., Conference on Fire Resistant Materials (Firemen). NASA Technical Memorandum 78523 (1978), National Aeronautics and Space Administration, Washington, DC.

(1.21) Tustin, E. A., Development of Fire Test Methods for Airplane Interior Materials, NASA CR-14568 (1979), National Aeronautics and space Administration, Washington, DC.

(1.22) Fewell, L. L., Flash-Fire Propensity and Heat-Release Rate Studies of Improved Fire Resistant Materials, NASA Technical Memorandum 78550 (1978), National Aeronautics and Space Administration, Washington, DC.

(1.23) Duskin, F. E., et al., Study to Develop Improved Fire Resistant Aircraft Passenger Seat Materials, Phase II, NASA CR-152184 (1979), National Aeronautics and Space Administration, Washington, DC.

(1.24) Lee, B. T. and Breese, J. N., Submarine Compartment Fire Study -Fire Performance Evaluation of Hull Insulation, NBSIR 78-1584, U.S. National Bureau of Standards, Washington, DC 20234 (1979).

(1.25) Chien, W. P., Nadeau, H. G., and Waszeciak, P. H., Development of a Small Compartment Corner Test Method for the Preliminary Evaluation of Fire Performance of Cellular Plastics, pp. 43-53 in Polyurethanes--Looking Ahead to the Eighties, Technomic, Westport, CT (1980).

(1.26) Budnick, E. K. and Klein, D. P., Mobile Home Fire Studies: Summary and Recommendations, NBSIR 79-1720, U.S. National Bureau of Standards, Washington, DC 20234 (1979). 
(1.27) Lee, B. T. and Walton, W. D., Fire Experiments and Flash Point Criteria for Solar Heat Transfer Liquids, NBSIR 79-1931, U.S. National Bureau of Standards, Washington, DC 20234 (1979).

(1.28) Gann, R. G., Development of Flammability Criteria for Transformer Dielectric Fluids, NBSIR 80-1992, U.S. National Bureau of Standards, Washington, DC 20234 (1980).

(1.29) Fire Research on Cellular Plastics: The Final Report of the Products Research Committee, Washington, DC (1980).

(1.30) Schaffer, E. L., Smoldering Initiation in Cellulosics Under Prolonged Low-level Heating, Fire Technology, Vol. 16, 22-28 (Feb, 1980).

(1.31) Kashiwagi, T., Experimental Observation of Radiative Ignition Mechanisms, Combustion and Flame, Vol. 34, 231-244 (Apr. 1979).

(1.32) Hilado, C. J. and Brauer, D. P., Ignition Testing of Fabrics and Fabric/Cushion Systems, Fire Technology, Vol. 15, 216-228 (Aug. 1979).

(1.33) Johnson, A. T., et al., Automatic Determination of Ignition Temperature, Fire Technology, Vol. 16, 181-191 (Aug. 1980).

(1.34) Flammability, Smoke, Toxicity, and Corrosive Gases of Electric Cable Materials (NMAB-342), National Research Council, Washington, DC (1978).

(1.35) Hunter, L. W., Models of Horizontal Electric Cables and Cable Trays Exposed to a Fire Plume, Combustion and Flame, Vol. 35, 311-322 (Aug. 1979).

(1.36) Bhatnagar, V. M., editor, Fire Retardants: Proceedings of 1978 International Symposium on Flammability and Fire Retardants, Technomic, Westport, CT (1979).

(1.37) Fire Retardant Chemicals Association Annual Meeting, 1979, Technomic, Westport, CT (1980).

(1.38) Day, M. and Wiles, D. M., Combustibility of Loose Fiber Fill Cellulose Insulation: The Role of Borax and Boric Acid, Journal of Consumer Product Flammability, Vol. 5, 113-122 (1978).

(1.39) Edelson, D., et al., Anomalous Behavior of Molybdenum Oxide as a Fire Retardant for Polyvinylchloride, Combustion and Flame, Vol. 38, 271-283 (Aug. 1980).

(1.40) Birky, M. M., Paabo, M., Levin, B. C., Womble, S., and Malek, D., Development of Recommended Test Method for Toxicological Assessment of Inhaled Combustion Products, NBSIR 80-2077, U.S. National Bureau of Standards, Washington, DC 20234 (Sept. 1980). 


\section{Chapter 2}

(2.1) Fire Resistance Ratings, American Insurance Association, 85 John Street, New York, NY.

(2.2) Fire Resistance Directory, Underwriters Laboratories, Inc. 333 Pfingsten Road, Northbrook, IL.

(2.3) Lin, T.D. and Abrams, M.S., Simulation of realistic restraint during fire tests of floor and roof assemblies. In the Proceedings of the International Symposium on Fire Safety of Concrete Structures, ACI meeting, Sept. 1980. American Concrete Institute, Box 19150, Detroit, MI.

(2.4) Bresler, B. and Iding, R., Fire response of prestressed concrete members. In the Proceedings of the International Symposium on Fire Safety of Concrete Structures, ACI meeting, Sept. 1980. American Concrete Institute, Box 19150, Detroit, MI.

(2.5) Gustaferro, A.H., Experiences from evaluating fire-damaged concrete structures. In the Proceedings of the International Symposium on Fire Safety of Concrete Structures, ACI meeting, Sept. 1980. American Concrete Institute, Box 19150, Detroit, MI.

(2.6) Fire Safety Aspects of Polymeric Materials, Vol. 7 Buildings. Publication NMAB-318-7, National Academy of Sciences, Washington, DC (1979).

(2.7) Holmes, C.A., Room corner-wall fire tests of some structural sandwich panels and components. Journal of Fire and Flammability Vol. 9, pp 467-488, (Oct. 1978).

(2.8) Condit, D.A. and Cianciolo, A.D., Evaluation of rigid urethane insulation for residential application by compartment corner fire test. Adv. Urethane Science Technology, Vol. 5, pp 26-38 (1979).

(2.9) Holmes, C.A., Eickner, H.W., Brenden, J.J. and White, R.H., Fire performance of structural flakeboard from forest residue. USDA Forest Service Research Paper, FPL No. 315, 20 p. (1979), Forest Products Laboratory, Madison, WI.

(2.10) Smith, A. and Williamson, R.B., Durability and fire-spread aspects of plastic pipe systems. Technical Report M-264, $67 \mathrm{p}$. (July 1979), Construction Engineering Research Laboratory, U.S. Army, Champaign, IL.

(2.11) Lacey, A.J., Fire endurance tests of cable penetration firestops in masonry walls and floors. IEEE Transactions on Power Apparatus and Systems, Vol. PAS-98, No. 4, pp. 1321-1325 (JulyAug. 1979), Institute of Electrical and Electronic Engineering, New York, NY. 
(2.12) Simpson, J., Jacisin, J.M., Butler, W.N. and Dombkowski, W.S., Fire testing of cable penetrations in telephone buildings. Presented at Fifth International Conference on Fire Safety, January 15, 1980, San Francisco, CA. Product Safety Corporation, Sunnyvale, CA 94087.

(2.13) --- Cable Penetration Fire Stop Qualification Test, IEEE Std. 634-1978. The Institute of Electrical and Electronics Engineers, Inc., New York, NY.

(2.14) Bresler, B. and Iding, R., Response of steel buildings to fire. Presented at ASCE Fall Convention, Session No. 43, Structural Research in Progress, ASCE Preprint No. 80-595 (Oct. 1980).

Chapter 3

(3.1) Abrams, M. S., Behavior of Inorganic Materials in Fire, Design of Buildings for Fire Safety, ASTM Special Technical Publication 685, PCA publication RD067.01M, pp. 14-75 (1979).

(3.2) Abrams, M. S., Performance of Concrete Structures Exposed to Fire, PCA Research and Development Bulletin RD060.01D, 7 pages (1979).

(3.3) Anon, Directory of Fire Research, Eighth Edition, The National Academy of Sciences, washington, DC (1978).

(3.4) Lie, T. T. and Williams-Leir, G., Factors Affecting Temperature of Fire-Exposed Concrete Slabs, Fire and Materials, Vol. 3, No. 2, pp. 74-79 (June 1979).

(3.5) Ellingwood, B. and Shaver, J., Fire Effects on Reinforced Concrete Members, National Bureau of Standards Technical Note 985, 42 pages (Aug. 1979), Washington, DC 20234.

(3.6) Lin, T. D. and Abrams, M. S., Temperature Distribution in Concrete Beams Subjected to Fire, presented at U.S. and U.S.S.R. joint seminar, Washington, DC (May 1980), in preparation for PCA publication.

(3.7) Nizamuddin, Z. and Bresler, B., Fire Response of Reinforced Concrete Slabs, ASCE Procedure Journal of the Structural Division, Vol. 105, No. ST8, pp. 1653-1671 (Aug. 1979).

(3.8) Lin, T. D. and Abrams, M. S., Simulation of Realistic Restraint During Fire Tests of Floor and Roof Assemblies, in the Proceedings of the International Symposium on Fire Safety of Concrete Structures, ACI meeting (Sept. 1980). 
(3.9) Bresler, B. and Iding, R., Fire Response of Prestressed Concrete Members, in the Proceedings of the International symposium on Fire Safety of Concrete Structures, ACI meeting (Sept. 1980).

(3.10) Gustaferro, A. H., Experience in the USA With the Use of Analytical Procedures for Determining Fire Resistance, paper in FIP Eighth Congress, Federation International de la Precontrainte (FIP) Proc., pp. 105-1ll (April 30-May 5, 1978).

(3.11) Gustaferro, A. H., Fire Resistance, Rational Design -- PCI Approach, paper in Concrete design: U.S. and European Practice, American Concrete Institute Special Publication SP-59, pp. 219-229 (1979).

(3.12) Lin, T. D., Gustaferro, A. H., and Abrams, M. S., Fire Endurance of Continuous Reinforced Concrete Beams, PCA publication RD72 (Dec. 1980).

(3.13) Lie, T. T., Calculating Resistance to Fire, Canada, National Research Council, Division of Building Research, Canadian Building Digest 204, 4 pages (May 1979).

(3.14) Byrne, S. M., Fire Resistance of Load-Bearing Masonry Walls, Fire Technology, Vol. 15, No. 3, pp. 180-188 (Aug. 1979).

(3.15) Schaffer, E., State of Structural Timber Fire Endurance, Wood and Fiber, Vol. 9, Issue 2, 145-170 (1977).

(3.16) Jeanes, D., Methods of Calculating Fire Resistance of Steel Structures--An Introduction, Engineering Applications of Fire Technology, Workshop Proceedings, April 1980, National Bureau of Standards, Washington, DC; published by Society of Fire Protection Engineers, Boston, MA (1981).

\section{Chapter 4}

(4.1) Liu, V. K. and Yang, K. T., UNDSAFE-II A Computer Code for Buoyant Flows in an Enclosure with Thermal Radiation, Notre Dame University TR-79002-78-3 (1978).

(4.2) Rehm, R. G., Cordes, M. R., Baum, H. R., and Lewis, J., A Linearized Finite Difference Computation of Fluid Heating in an Enclosure, NBSIR 79-1754, U.S. National Bureau of Standards, Washington, DC (1979).

(4.3) Emmons, H. W., Mitler, H. E., and Trefethen, L. M., Computer Fire Code III, Home Fire Project, TR 25, Harvard University, Cambridge, MA (1978).

(4.4) Mitler, H. E., The Physical Basis for the Harvard Computer Fire Code, Home Fire Project, TR 34, Harvard University, Cambridge, MA (1978). 
(4.5) Pape, R. and Waterman, T., Modification to the RFIRES Preflashover Room Fire Computer Model, IITRI Project J 6400; Final Report, U.S. National Bureau of Standards, Washington, DC (1977).

(4.6) Quintiere, J. G., McCaffrey, B. J., and Den Braven, K., Experimental and Theoretical Analysis of Quasi-Steady Small-Scale Enclosure Fires, 17th (International) Symposium on Combustion, Leeds, England (1978).

(4.7) MacArthur, C. D. and Myers, J. F., Dayton Aircraft Cabin Fire Model Validation, FAA Report FAA-RD-78-57 (1978).

(4.8) Smith, E. E., Evaluating Performance of Cellular Plastics in Fire Systems, Final Report for Products Research Committee Grant RP-75$1-36$ (1978).

(4.9) Quintiere, J. G. and McCaffrey, B. J., The Burning of Wood and Plastic Cribs in an Enclosure, Products Research Committee RP-76U-2, NBSIR 80-2054, U.S. National Bureau of Standards, Washington, DC (1979).

(4.10) Babrauskas, V. and williamson, R. B., Post-Flashover Compartment Fires: Basis of a Theoretical Model, Fire Materials, Vol. 2, 39-53 (1978).

(4.11) Zukowski, E. E., Development of a Stratified Ceiling Layer in the Early Stages of a Closed-Room Fire, Fire Materials, Vol. 2, 54-62 (1978).

(4.12) Thomas, P. H., Bullen, M. L., Quintiere, J. G., and McCaffrey, B. J., Flashover and Instabilities in Fire Behavior, Combustion and Flame, Vol. 38, 159-171 (1980).

(4.13) Zukoski, E. E. and Kubota, T., Two-Layer Modeling of Smoke Movement in Building Fires, Fire Materials, Vol. 4, 17-27 (1980).

(4.14) Zukoski, E. E., Kubota, T., and Cetegen, B., Entrainment in Fire Plumes, California Institute of Technology, Pasedena, CA (April 1980).

(4.15) Baum, H. R. and Mulholland, G. W., Coagulation of Smoke Aerosol in a Buoyant Plume, Journal of Colloidal Interface Science, Vol. 72, $1-12$ (1979).

(4.16) Heskestad, G. and Delichatsios, M. A., The Initial Convective Flow in Fire, 17th (International) Symposium on Combustion, Leeds, England (1978).

(4.17) Orloff, L., Simplified Radiation Modeling of Pool Fires, Factory Mutual Research Corporation J.I. Report No. OElEO.BU-1, Norwood, MA. 
(4.18) Orloff,, L., Modak, A. T., and Markstein, G. H., Radiation From Smoke Layers, 17th (International) Symposium on Combustion, Leeds, England (1978).

(4.19) Modak, T. A. and Mathews, M. K., Radiation Augmented Fires within Enclosures, Journal of Heat Transfer, Vol. 100, 544-547 (1978).

(4.20) de Ris, J., Fire Radiation - A Review, 17th (International) Symposium on Combustion, Leeds, England (1978).

(4.21) Frey, A. E. and T'ien, J. S., A Theory of Flame Spread Over a Solid Fuel Including Finite-Rate Chemical Kinetics, Combustion and Flame, Vol. 36, 263-289 (1979).

(4.22) Altenkirch, R. A., Eichhorn, R., and Shang, P. C., Buoyancy Effects on Flames Spreading Down Thermally Thin Fuels, Combustion and Flame, Vol. 37, 71-83 (1980) .

(4.23) Fernandez-Pello, A. C., Ray, S. R., and Glassman, I., Eighteenth (International) Symposium on Combustion, Waterloo, Canada (1980).

(4.24) Fernandez-Pello, A. C., Flame spread in a Forward Forced Flow, Combustion and Flame, Vol. 36, 63-78 (1979).

(4.25) Carrier, G., Fendell, F., and Feldman, P., Wind Aided Flame Spread Along a Horizontal Fuel Slab, Combustion Science Technology, Vol. 23, 41-78 (1980).

(4.26) Baum, H. R., An Alternative Derivation of Some Flame Spread Integral Equations, Combustion Science Technology, Vol. 23, 79-82 (1980).

(4.27) Tamanini, F., A Numerical Model for the Prediction of RadiationControlled Turbulent Wall Fires, 17th (International) Symposium on Combustion, Leeds, England (1978).

(4.28) Ahmad, T. and Faeth, G. M., Turbulent Wall Fires, 17th (International) Symposium on Combustion, Leeds, England (1978).

(4.29) Tewarson, A., Lee, J. L., and Pion, R. F., The Influence of Oxygen Concentration on Fuel Parameters for Fire Modeling, Eighteenth (International) Symposium on Combustion, Waterloo, Canada (1980).

(4.30) Quintiere, J. G., McCaffrey, B. J., and Rinkinen, W., Visualization of Room Induced Smoke Movement and Flow in a Corridor, Fire Materials, Vol. 2, 18-24 (1978).

(4.31) Alpert, R. L., Pressure Modeling of Upward Fire Spread, Factory Mutual Research Corporation, Report No. OAOR8.BU, Norwood, MA (March 1979). 
(4.32) Williams, F. W. and Jones, W. W., Scaling of Fire Behavior, Naval Research Laboratory Review, Washington, DC (1979).

(4.33) Schmidt, Jr., L. A., A Parametric Study of Probabilistic Fire Spread Effects, Institute for Defense Analysis Report No. IDA-P-1372 (1979).

(4.34) Emmons, H. W., Scientific Progress on Fire, Annual Review Fluid Mechanics, Vol. 12, 223-236 (1980).

(4.35) Emmons, H. W., The Prediction of Fires in Buildings, 17th (International) Symposium on Combustion, Leeds, England (1978).

(4.36) Emmons, H. W., Fire, 8th U.S. Congress on Applied Mechanics, Univ . of Calif., Berkeley, CA (June 1978).

(4.37) Quintiere, J. G., The Spread of Fire From a Compartment - A Review, Special Technical Paper 685, American Society for Testing and Materials, Philadelphia, PA (1980).

\section{Chapter 5}

(5.1) Modak, A. T. and Orloff, L., Fires of Insulations on Tank Exteriors, Fire Technology, Vol. 16, No. 2, p. 118 (May 1980).

\section{Chapter 6}

(6.1) Harpe, S. W. and Christian, W. J., Development of a Smoldering Fire Test for Household Smoke Detectors, Fire Journal, Vol. 73, No. 3, p. 48-53 (May 1979).

(6.2) Nelson, H. N., The Need for Full Function Test Features in Smoke Detectors, Fire Technology, Vol. 15, 10-19 (1979).

(6.3) Litton, C. D., Optimizing Ionization-Type Smoke Detectors, Fire Technology, Vol. 15, 25-42 (1979).

(6.4) Solomon, E. E. and Reiss, M. H., The Requirements and Design for Combined Ionization/Photoelectric Smoke Detectors, Fire Journal, Vol. 73, No. 5, pp. 45-55 (Sept. 1979).

(6.5) Bukowski, R. W. and Mulholland, G. W., Smoke Detector Design and Smoke Properties, National Bureau of Standards Technical Note 973, Washington, DC (Nov. 1978).

(6.6) Street, T. T., Williams, F. W., and Alexander, J. I., Logic Aided Fire Detection System, Journal Fire and Flammability, Vol. 11, p. 212-220 (July 1980). 
(6.7) Johnson, J. E., How Much Radioactivity is There in Smoke Detectors?, Fire Journal, Vol. 73, No. 6, pp. 35-39 (Nov. 1979).

(6.8) Moore, D. A., Remote Detection and Alarm for Residences: The Woodlands System, Fire Journal, Vol. 74, No. 1, pp. 57-61 (Jan. 1980).

(6.9) Bukowski, R. W., Investigation of the Effects of Heating and Air Conditioning on the Performance of Smoke Detectors in Mobile Homes, NBSIR 79-1915, U.S. National Bureau of Standards, Washington, DC (Oct. 1979).

(6.10) Powell, E. A., Bankston, C. P., Cassanova, R. A., and Zinn, B. T., The Effect of Environmental Temperature upon the Physical Characteristics of the Smoke Produced by Burning Wood and PVC Samples, Fire and Materials, Vol. 3, pp. 15-22 (1979).

(6.11) Heskestad, G. and Delichatsios, M. A., The Initial Convective Flow in Fire, Seventeenth (International) Symposium on Combustion, The Combustion Institute, Pittsburgh, PA, pp. 1113-1123 (1979).

(6.12) Zukoski, E. E. and Kubota, T., Two-Layer Modeling of Smoke Movement in Building Fires, Fire and Materials, Vol. 4, 17-27 (1980).

(6.13) Rajan, K. S., Snelson, A., and Mainer, S., Chelation-Photoelectric Concept for Fire Detection, Fire Technology, Vol. 16, 104-112 (1980).

(6.14) Willey, A. E., Factors in Unsuccessful Smoke Detector Performance in Residential Occupancies, Fire Journal, Vol. 73, No. 3, 42-45 (May 1979).

(6.15) Heskestad, G., The Role of Water in Suppression of Fire: A Review, Journal of Fire and Flammability, Vol. 12, 254-262 (1980).

(6.16) Corlett, R. C. and Williams, F. A., Modeling Direct Suppression of Open Fires, Fire Research, Vol. 1, 323-337 (1978/79).

(6.17) Sibulkin, M., Little, M. W., and Kulkarni, A., Effects of $\mathrm{N}_{2}$ and $\mathrm{CF}_{3} \mathrm{Br}$ on Extinction of Propagating and Fully Burning Fires, Journal of Fire and Flammability, Vol. 10, p. 263-273 (Oct. 1979).

(6.18) Ball, J.A. and Pietrzak, L. M., Investigation to Improve the Effectiveness of Water in the Suppression of Compartment Fires, Fire Research, Vol. 1, 291-300 (1977/78).

(6.19) Yao, C., Performance and Criteria-Automatic Sprinkler Systems, CIB Symposium, Tsukuba, Japan, August 1979. Published by Secretariat for CIB Symposium, Kenchiku Kenkyu Shinko Kyokai, Nakajima Building, 1-8-1 Kitashinjuku, Shinjuku-ku, Tokyo, Japan.

(6.20) Moore, D. A., Field Test and Evaluation of Residential sprinkler Systems, Fire Journal, Vol. 74, No. 6, 44-47 (Nov. 1980). 
(6.21) Suchomel, M. R. and Castino, G. T., Sprinkler Performance Tests-The Extended Coverage Panacea, Fire Technology, Vol. 16, 85-93 (May 1980).

(6.22) Ault, W. E., The Use of Light-Wall and Special Light-Weight Pipe in Automatic Sprinkler Systems, Fire Journal, Vol. 73, No.6, 62-64, 91 (Nov. 1979).

\section{Chapter 7}

(7.1) Lieff, M., personal communication, Nov. 1, 1978; updated Dec. 1980.

\section{Chapter 8}

(8.1) Bukowski, R. W., Tests on the Performance of Automatic Fire Detectors in Health Care Occupancies - A Preliminary Report, NBSIR 79-1739, U.S. National Bureau of Standards, Washington, DC (April 1979), NTIS Order No. PB-297150.

(8.2) Collins, B. L. and Pierman, B. C., Evaluation of Safety Symbols, NBSIR 79-1760, U.S. National Bureau of Standards, Washington, DC (June 1979), NTIS Order No. PB-298175.

(8.3) Glass, R. A. and Rubin, A. I., Fire Safety for High-Rise Buildings: The Role of Communications, National Bureau of Standards Building Science Series 115 (April 1979), GPO Stock No. 003-003-02016-8.

(8.4) Groner, N. E., Loftus, E. F., and Keating, J. P., Calling Nurse Blaze: Tailoring Programs to Fit Human Behavior, Journal of the American Hospital Association, Vol. 52, No. 14, 111-115 (July 16, 1978).

(8.5) Loftus, E. F., Words That Could Save Your Life, Psychology Today, Vol. 13, No. 6, 102-103, 105-106, 110, 136-137 (Nov. 1979).

(8.6) Pezoldt, V. J. and Van Cott, H. P., Arousal from Sleep by Emergency Alarms: Implications from the Scientific Literature, NBSIR 78-1484 (HEW), U.S. National Bureau of Standards, Washington, DC (June 1978).

(8.7) Pierman, B. C. and Lerner, N. D., Testing Symbols for Fire Situations, Fire Command, Vol. 47, No. 3, 12-13 (March 1980).

(8.8) Archea, J. and Margulis, S. T., Editor, The Evacuation of NonAmbulatory Patients from Hospital and Nursing Home Fires: A Framework for a Model. NBSIR 79-1906, U.S. National Bureau of Standards, Washington, DC (Nov. 1979), NTIS Order No. PB 80-119530. 
(8.9) Berlin, G. N., A Modeling Procedure for Analyzing the Effect of Design on Emergency Escape Potential. In: Second International Seminar on Human Behavior in Fire Emergencies, October 29 November 1, 1978--Proceedings of Seminar, pp. 13-41. NBSIR 80-2070, U.S. National Bureau of Standards, Washington, DC (June 1980).

(8.10) Francis, R. L. and Saunders, P. B., EVACNET: Prototype Network Optimization Models for Building Evacuation, NBSIR 79-1738, U.S. National Bureau of Standards, Washington, DC (Oct. 1979), NTIS Order No. PB 80-113780.

(8.11) Horiuchi, S., An Experimental Study on Exit Choice Behavior of Occupant in an Evacuation under Building Fire. In: Second International Seminar on Human Behavior in Fire Emergencies, October 29 - November 1, 1978--Proceedings of Seminar, pp. 173-185. NBSIR 80-2070, U.S. National Bureau of Standards, Washington, DC (June 1980).

(8.12) Seeger, P. G. and John, R., Evacuation Tests in High-Rise Office Buildings and in Large 2-Story Buildings. In: Second International Seminar on Human Behavior in Fire Emergencies, October 29 - November 1, 1978--Proceedings of Seminar, pp. 221-247. NBSIR 80-2070, U.S. National Bureau of Standards, Washington, DC (June 1980).

(8.13) Stahl, F. I., BFIRES/Version 2: Documentation of Program Modifications, NBSIR 80-1982, U.S. National Bureau of Standards, Washington, DC (March 1980).

(8.14) Stahl, F. I., A Computer Simulation of Human Behavior in Building Fires: Interim Report, NBSIR 78-1514, U.S. National Bureau of Standards, Washington, DC (Sept. 1978), NTIS Order No. $\mathrm{PB}-289272$.

(8.15) Stahl, F. I., Final Report on the "BFIRES/Version 1" Computer Simulation of Emergency Egress Behavior During Fires: Calibration and Analysis, NBSIR 79-1713, U.S. National Bureau of Standards, Washington, DC (March 1980).

(8.16) Stahl, F. I., Preliminary Findings Concerning the Validity of "BFIRES": A Comparison of Simulated with Actual Fire Events. In: Second International Seminar on Human Behavior in Fire Emergencies, October $29^{\circ}$ - November 1, 1978--Proceedings of Seminar, pp. 249-258. NBSIR 80-2070, U.S. National Bureau of Standards, Washington, DC (June 1980), NTIS Order No. PB 80-204738.

(8.17) Stahl, F. I. and Archea, J., An Assessment of the Technical Literature on Emergency Egress from Buildings, NBSIR 77-1313, U.S. National Bureau of Standards, Washington, DC (Oct. 1977), NTIS Order No. PB-273944.

(8.18) Vreeland, R. G. and Waller, M. B., Personality Theory and Firesetting: An Elaboration of a Psychological Model, University of North Carolina, Chapel Hill, National Bureau of Standards Report No. NBS-GCR-80-194, (Feb. 1980), NTIS Order No. PB 80-161599. 
(8.19) Vreeland, R. G. and Waller, M. B., The Psychology of Firesetting: A Review and Appraisal, University of North Carolina, Chapel Hill, National Bureau of Standards Report No. NBS-GCR-79-157, (Jan. 1979), NTIS Order No. PB-290821.

(8.20) Bell, J. R., Fourteen Die in Ohio Boarding Home Fire, Fire Journal, Vol. 74, No. 4, 28-31, 87 (July 1980).

(8.21) Berl, W. G. and Halpin, B. M., Human Fatalities from Unwanted Fires, The Johns Hopkins University, Applied Physics Laboratory. National Bureau of Standards Report No. NBS-GCR-79-168, (Dec. 1978), NTIS Order No. PB-295411.

(8.22) Bryan, J. L. and DiNenno, P. J., An Examination and Analysis of the Dynamics of the Human Behavior in the Fire Incident at the Georgian Towers on January 9, 1979. University of Maryland. National Bureau of Standards Report No. NBS-GCR-79-187, (Dec. 1979), NTIS Order No. PB 80-148596.

(8.23) Bryan, J. L. and DiNenno, P. J., An Examination and Analysis of the Human Behavior in the Fire Incident at the National Institutes of Health Clinical Center on April 21, 1979. University of Maryland. National Bureau of Standards Report No. NBS-GCR-80-192 (Jan. 1980), NTIS Order No. PB 80-177264.

(8.24) Bryan, J. L. and DiNenno, P. J., An Examination and Analysis of the Dynamics of the Human Behavior in the Fire Incident at the University Nursing Home on April 13, 1979. University of Maryland. National Bureau of Standards Report No. NBS-GCR-80-191 (Jan. 1980), NTIS Order No. PB 80-158157.

(8.25) Bryan, J. L. and DiNenno, P. J., Human Behavior in a Nursing Home Fire, Fire Journal, Vol. 74, No. 3, 44-47, 141-142 (May 1980).

(8.26) Bryan, J. L., DiNenno, P. J., and Milke, J. A., The Determination of Behavior Response Patterns in Fire Situations, Project People II, Final Report - Incident Reports, August 1977 to June 1980, University of Maryland. National Bureau of Standards Report No. NBS-GCR-80-297 (Dec. 1980).

(8.27) Bryan, J. L., Milke, J. A., and DiNenno, P. J., An Examination and Analysis of the Dynamics of the Human Behavior in the Fire Incident at the Taylor House on April 11, 1979. University of Maryland. National Bureau of Standards Report No. NBS-GCR-80-200, (April 1980), NTIS Order No. PB 80-179054.

(8.28) Edelman, P., Herz, E., and Bickman, L., A Model of Behaviour in Fires Applied to a Nursing Home Fire. In: Fires and Human Behaviour, edited by David Canter, Chapter 11, pp. 181-203, John Wiley \& Sons, New York, New York, (1980). 
(8.29) Kobayashi, M. and Horiuchi, S., Analysis of Occupant Behavior in an Office Building under Fire. In: Second International Seminar on Human Behavior in Fire Emergencies, October 29 - November 1, 1978--Proceedings of Seminar, pp. 187-201. NBSIR 80-2070, U.S. National Bureau of Standards, Washington, DC (June 1980).

(8.30) Lerup, L., Cronrath, D., and Liu, J. K. C., Fires in Nursing Facilities. In: Fires and Human Behaviour, edited by David Canter, Chapter 10, pp. 155-180, John Wiley \& Sons, New York, New York, (1980).

(8.31) Swartz, J. A., Human Behavior in the Beverly Hills Fire, Fire Journal, Vol. 73, No. 3, 73-74, 108 (May 1979).

(8.32) Levin, B. M., Editor, Fire and Life Safety for the Handicapped, National Bureau of Standards Special Publication 585, (July 1980), U.S. Government Printing Office, Washington, D.C.

(8.33) Levin, B. M. and Paulsen, R. L., Editors, Second International Seminar on Human Behavior in Fire Emergencies, October 29 - November 1, 1978--Proceedings of Seminar, NBSIR 80-2070, U.S. National Bureau of Standards, Washington, DC (June 1980), NTIS Order No. PB 80-204738.

(8.34) Jones, C. E. and Fechter, J. V., Safe Environments--Anthropometric, Biomechanical, and Activity Considerations, NBSIR 80-2014, U.S. National Bureau of Standards, Washington, DC (June 1980), NTIS Order No. PB 80-199128.

(8.35) Overboe, C. J. and Wang, Y. Y., Behavioral and Physical Characteristics of Developmentally Disabled Individuals, Waisman Center, University of Wisconsin, Madison, Wisconsin. National Bureau of Standards Report No. NBS-GCR-79-167 (March 1979), NTIS Order No. PB-294970.

(8.36) Ramey-Smith, A. M. and Fechter, J. V., Group Homes for the Developmentally Disabled: Case Histories of Demographics, Household Activities, and Room Use, NBSIR 79-1727, U.S. National Bureau of Standards, Washington, DC (April 1979), NTIS Order No. PB-295037. 


\section{APPENDIX}

\section{Fire Resistant Coverings}

(General Characteristics of the Material, Methods of Application, Methods of Testing and Research Results)

Prepared by

Morris Lieff, Ph.D., P.E.

Professor of Chemistry Chairman, Division of Mathematics

Physical Sciences and

Industrial Technologies

County College of Morris

Dover, NJ

as part of the

US-USSR AGREEMENT ON COOPERATION IN

THE FIELD OF HOUSING AND OTHER CONSTRUCTION

JOINT WORKING GROUP 10.03, BUILDING MATERIALS AND COMPONENTS

PROJECT 10.03.01.06 "FIRE RESISTANCE OF BUILDINGS AND STRUCTURES"

November 1, 1978 



\section{Introduction}

Fire resistancel is defined as "the property of a material or assembly to withstand fire or give protection from it. As applied to elements of buildings, it is characterized by the ability to confine a fire or to continue to perform a given structural function or both." Fire retardantl is defined as "having or providing comparatively low flammability or flame spread properties."

The thickness of covering used to provide protection for building in fire environments is dependent on the need, and is basically determined by the substrate. Thin coatings, which are generally called fire retardant paints, are applied over wood or cellulosic building materials to reduce combustibility or surface flame spread. Thick coatings are used to provide fire resistive protection of steel. In order to develop fire resistive ratings, the absorption of heat by the structural steel must be minimized. This is achieved by thickness ranging from $1 / 8$ in $(3 \mathrm{~mm})$ to 2 in $(50 \mathrm{~mm})$ or more. Intumescent mastic coatings are at the lower thickness range of $1 / 8-1 / 4$ in (3-6 mm), whereas cementitious and fibrous covering range from $3 / 8(9.5 \mathrm{~mm})$ to $2(50 \mathrm{~mm})$ or more inches.

\section{Fire Retardant Coverings}

Fire retardant coverings (paints) which help shield underlying surfaces from damage by fire have shown a growing use in recent years. They are designed for life safety rather than building protection. They are used for example to protect the walls and ceilings of hospitals, nursing homes, schools and ships. They can provide 10 to 20 minutes of additional time in which to evacuate safely the occupants from within the building. They find their greatest usage in areas such as stairwells, corridors, or where safe egress is necessary. Such locations in the building require that the flame spread of the materials used be very low.

Fire retardant paints serve to delay ignition and to reduce the flame spread of a combustible surface. They provide a protective layer which accomplishes these objectives in a number of ways.

1) provide a non-combustible layer over the flammable surface

2) liberates inhibiting gases

3) absorbs heat on decomposition

\footnotetext{
$\mathrm{l}_{\text {ASTM Designation }}$ E-176-73, Standard Definitions of Terms Relating to Fire Tests of Building Construction and Materials.
} 
4) liberates water when heated, maintaining the temperature at $100^{\circ} \mathrm{C}$ for an extended period of time

5) on heating accelerates the formation of char

6) Swells in heating (intumesces) thus providing an insulating layer over the surface

Most fire retardant paints rely on a combination of several of these actions for their effectiveness.

Fire retardant paints may be usefully divided into two broad categories.

1) Intumescent

2) Inert (do not intumesce)

Fire retardant paints which intumesce are more effective than non-intumescent. These coatings when heated expand by foaming to produce a cellular carbonaceous material that insulates the substrate from heat. Four types of compounds interact to form this insulating layer, namely:

a) a polyhydric compound to act as a carbon source (carbonific)

b) a dehydrating agent which is the intumescent catalyst

c) a blowing agent

d) a resin binder

Exposure of the intumescent coating to a high enough temperature causes the compound providing the carbon to react with the dehydrating agent to form a char. Simultaneously, the release of copious quantities of nonflammable gases by the blowing agent causes the char to expand greatly. The resin binder forms a thin layer over the foam and inhibits the escape of the gas. The resulting, greatly expanded coating, often more than 100 times as thick as the original coating, retards the spread of flames by preventing their contact with the combustible substrate.

Carbonifics generally used as a carbon source are a mono-, di, or tri pentaerythritol or starch. The most commonly used catalyst is monoammonium phosphate or water insoluble ammonium polyphosphate. The phosphoric acid formed by heating the phosphate reacts with the carbonific to accelerate the char formation. Melamine, which releases ammonia when heated, or chlorinated paraffins which release hydrogen chloride, serve as blowing agents. Emulsion vinyl copolymer that melts or softens at the appropriate temperature is a common resin binder. Melamine-formaldehyde and epoxy resins may also be used.

Non-intumescent fire retardant paints are based primarily on

1) chlorinated alkyds, or

2) alumina trihydrate, or

3) combination of chlorinated paraffins and antimony trioxide 
Flame retardancy is believed to result from the presence in the retardant of one or more key elements such as phosphorus, nitrogen, chlorine or a volatile compound such as water of hydration.

Phosphorus is believed to act as a flame retardant because of its ability to increase markedly the conversion of organic matter to elemental carbon (char) during burning, and thus to decrease greatly the formation of flammable gases. Combustion is also inhibited because the char does not burn readily and interferes with the access of oxygen and heat to the underlying surface.

Nitrogen. The role of nitrogen is not well understood. It is believed by some that nitrogen is useful only in the presence of phosphorus as in such compounds as diammonium phosphate.

Chlorine and Bromine are believed to act in the gas phase. The hydrogen chloride or hydrogen bromide which is released by the flame retardant on heating reacts with hydrogen, hydroxyl, and oxygen free radicals removing them from the burning gas. The combustion process is suppressed by the prevention of the exothermic reactions in which these free radicals participate.

Antimony trioxide $\left(\mathrm{Sb}_{2} \mathrm{O}_{3}\right)$ by itself is ineffective. However, it is very effective when used with a halogenated flame retardant, which upon heating releases either hydrogen chloride or hydrogen bromide. Released hydrogen chloride reacts with solid antimony trioxide to form antimonychloride $\left(\mathrm{SbCl}_{3}\right)$ and antimony oxychloride $\left(\mathrm{SbOCl}_{3}\right)$ both of which are gases. Transported to the flame, these gases interfere with combustion and can cause the flame to be extinguished by reacting with both hydrogen and hydroxyl free radicals.

Alumina Trihydrate suppresses burning by absorption of heat due to decomposition, at $220^{\circ} \mathrm{C}$ to $230^{\circ} \mathrm{C}$ into anhydrous alumina and water vapor, which dilutes and cools the combustible gases.

Testing of Fire Retardant Coatings

The standard method for evaluating the effectiveness of a fire retardant paint is ASTM E 84, standard Test for Surface Burning Characteristics of Building Materials (alșo known as UL 723, NFPA 225).

This test method measures the "flame spread" (defined by ASTM E 176 as "flaming combustion along a surface"), that is, the value of relative flammability developed in the $25 \mathrm{ft}(7.6 \mathrm{~m})$ long horizontal testing funnel. The tunnel is essentially a long horizontal flue in which the test samples form the ceiling of this tunnel-furnace. An igniting flame located at the end of the funnel. causes ignition of any combustibles present. The test panel is subjected to the flame for 10 minutes during which time the flame front is observed. The maximum flame progress, the temperature of the exit gases and the density of the smoke generated are recorded. 
The tunnel is standardized by using 1 inch red-oak wood flooring with an arbitrarily assigned flame spread rating of 100, and asbestoscement board, 1/4 inch thick, on the other end of the scale with a rating of zero. Fuel contribution and smoke developed by the test material is calculated from the increase in smoke and exit gas temperature achieved when burning the test specimen. Numerical classifications are thus established for flame spread, fuel contributed, and smoke, which permits the fire performance of the material to be compared with asbestos-cement and red-oak flooring.

In the United States there are many fire retardant coatings on the market, their formulae being of a proprietary (commercial secret) nature. They are used primarily where they are required by building codes and government regulatory agencies. To meet these regulations, the fire retardant coatings must be tested by an institution such as Underwriters Laboratories Inc. (UL), which lists the test result in its annual "Building Materials Directory."2 To qualify for listing by UL as a fire retardant coating, the paint must reduce the flame spread of Douglas fir at least 50 percent. Pages 71 to 89, of the 1980 Building Materials Directory list the values of the flame spread, fuel contributed and smoked developed of many commercially available products whose formulae are of a proprietary nature. Similarly, the Factory Mutual System publishes annually an "Approval Guide of Equipment, Materials and Services for Conservation of Property." (Fire Retardant Coatings, pages 425-426.)

\section{Fire Resistive Coverings}

The wide use of modern steel-framed buildings has fostered the development of light weight, fire resistive coverings. Although steel is noncombustible, it must be protected from unsafe temperatures developed in intense fires which may cause loss of its structural strength and structural failure.

For many years structural steel framing was encased in heavy masonry to provide fire protection. However, recent research and development in fire protection technology has produced highly efficient, lightweight fire resistive coverings as well as innovative application techniques which afford significant cost savings. ${ }^{3}$

\footnotetext{
2 See Appendix A. Institute.

1. "Fire Resistant Steel-Frame Construction"

2. "Designing Fire Protection for Steel Columns"

3. "Designing Fire Protection for Steel Trusses"
}

3 Excellent reviews of such developments in steel-frame construction may be found in the following publications of the American Iron and steel 
Fire protection of steel floor and roof systems and related structural elements can be achieved by two general methods, first, by contact or directly applied fire protection or second, by membrane fire protection.

In contact fire protection the fire resistive covering or coating is spray-applied directly to the surfaces of the structural components. In floor and roof systems for example, the sprayed mineral fiber is applied following the contour to the underside of the formed steel decking and exposed surfaces of the supporting steel.

In membrane fire protection, a fire resistive barrier is created by applying the fire resistive material as a ceiling below the floors or roofs, or by encasing the individual columns or beams and trusses.

There are three basic types of fire resistive materials:
a) insulative materials
b) energy absorbing (ablative) materials
c) intumescent coatings

Most of the commonly used materials are actually combinations of the first two types, since they contain varying proportions of insulative and energy absorbing materials. Intumescent coatings also absorb small amounts of energy when heated. The most widely used insulating materials with excellent thermal qualities are mineral fibers, and vermiculite and perlite which are expanded aggregates. Commonly used energy absorbing materials are gypsum, and portland cement which release water when heated. Magnesium oxychloride is also used but in limited quantities, because of its much higher cost.

Most contact fire resistive coverings used are either of the sprayed mineral fiber or cementitious types. The sprayed mineral fiber fire resistive coatings are blends of mineral fibers and inorganic binders, which are applied directly to the surface being protected. The fibrous material is blown through a special spray gun which combines fibers air and water at the nozzle. The material is deposited as an insulating blanket in the continuous application following the contour of the formed steel deck and beams to the required thickness, at the rate of 40-50 $\mathrm{ft}^{3} / \mathrm{hr}\left(1.1-1.4 \mathrm{~m}^{3} / \mathrm{hr}\right)$. The dry density of the applied material generally ranges from 12 to $15 \mathrm{lbs} / \mathrm{ft}^{3}\left(190-240 \mathrm{~kg} / \mathrm{m}^{3}\right)$. In addition to their excellent thermal insulating qualities, these materials have high sound absorption properties. Recently asbestos was a component of the mineral fibers blend. However, because of potential health hazards, present products are made of rock or slag mineral wood fibers and contain no asbestos. 
An interesting example of the use of sprayed mineral fiber fire protection may be found at the world Trade Center in Moscow. This structure is of steel-frame construction, with steel form floors, beams and columns all being protected with an American-made sprayed mineral fiber product.

The principal cementitious type of sprayed fire resistive material consists of expanded vermiculite aggregate, hydraulic binders such as gypsum or clay and a foaming agent. The material is premixed with water to a plaster consistency, and then machine applied directly to the steel surfaces. Dry densities of the cementitious covering range from 18 to $24 \mathrm{lbs} / \mathrm{ft}^{3}\left(290-385 \mathrm{~kg} / \mathrm{m}^{3}\right)$.

\section{Test Method}

Buildings of fire resistive construction consist of elements which have been assigned fire resistance ratings expressed in hours. The hourly ratings by which the degree of fire resistance is expressed are outlined in the American Society for Testing and Materials ASTM E 119, "Standard Methods of Fire Tests of Building Construction and Materials." (Also known as UL 263, ANSI A2.1, NFPA 251.) This test method evaluates the ability of a structure to act as a barrier to the spread of fire and to confine it to the areas of origin. Fire resistance ratings expressed in hours are assigned to the assembly or component on the basis of the time that it is able to withstand exposure to the standard fire before a condition of failure is reached. In judging when an assembly such as floors, roofs, beams, columns, and walls no longer act as a barrier in a test, such criteria as structural capability under full load, limiting steel temperatures, passage of excessive heat, flame or hot gases through the assembly may be used.

Proprietary fire resistive coverings which have been successfully tested in hundreds of assemblies at Underwriters Laboratories are published annually in Underwriters Laboratories Inc., "Fire Resistance Directory, "4 which contains hourly ratings for beams, columns, floors, roofs, walls, and partitions. Factory Mutual Research in their "Approval Guide 1978," lists tested assemblies in the section "Building Material and Construction." Listed designs are identified in the UL Fire Resistance Directory with an alpha-numerical design number. The prefix letter designates the type of construction, and the three digit number the type of fire resistive covering. For example, prefix letters:

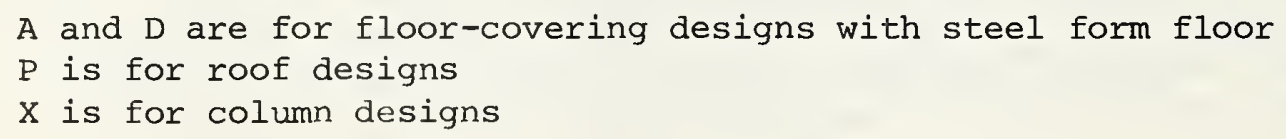

Membrane protection uses numbers from 0 to 500. Contact (direct applied) protection uses 600 series for miscellaneous materials including intumescent mastics; 700 series for cementitious materials; and, 800 series for sprayed fiber fire resistive coverings. 


\section{APPENDIX LIST}

A. UL Building Materials Directory, January 1980

B. UL Fire Resistance Directory, January 1980 
BIBLIOGRAPHIC DATA

SHEET (See in structions)

1. PUBLICATION OR
REPORT NO.
NBSIR $81-2294$

2. Performing Organ. Report Noy 3. Publication Date

June 1981

4. TITLE AND SUBTITLE

Survey of United States Research Projects Publications in the Field of Fire Safety of Buildings and Structures - 1978-1980

\section{5. $\operatorname{AUTHOR}(S)$}

R. S. Levine, Editor

6. PERFORMING ORGANIZATION (If joint or other than NBS, see instructlons)

7. Contract/Grant No.

NATIONAL BUREAU OF STANDARDS

DEPARTMENT OF COMMERCE

8. Type of Report \& Period Covered

WASHINGTON, D.C. 20234

9. SPONSORING ORGANIZATION NAME AND COMPLETE ADDRESS (Street, City. Stote, ZIP)

10. SUPPLEMENTARY NOTES

Document describes a computer program; SF-185, FIPS Software Summary, is attached.

11. ABSTRACT (A 200-word or less foctual summary of most significant information. If document includes a significant bibliogrophy or literature survey, mention it here)

This report is an annotated bibliography of some 166 U.S. papers on fire safety research, published 1978-1980. Prepared as part of a US-USSR agreement to cooperate in this field, it includes chapters on testing materials for flammability,. smoke generation and toxicity, fire resistance of structures, compartment fire modeling, automatic detection and suppression, and human response in fires.

12. KEY WORDS (Six to twelve entries; alphabetical order; capitalize only proper nomes; ond separote key words by semicolons) Compartment fires; fire detection; fire endurance; fire tests; fire modeling; flammability; human behavior; smoke; suppression; toxicity

13. AVAILABILITY

[区] Unlimited

$\square$ For Official Distribution. Do Not Release to NTIS

$\square$ Order From Superintendent of Documents, U.S. Government Printing Office, Washington, D.C. 20402.

X] Order From National Technical Information Service (NTIS), Springfield, VA. 2216I
14. NO. OF PRINTED PAGES

43

15. Price

$\$ 6.50$ 

